\title{
Relation of microscopic haematuria in ankylosing spondylitis to circulating IgA containing immune complexes
}

\author{
ANDRÉ J PEETERS, ${ }^{1}$ A WARMOLD L VAN DEN WALL BAKE, \\ ANNETTE D VAN DALSEN, AND MARIE-LOUISE WESTEDT ${ }^{1}$ \\ From the Departments of ' Rheumatology and ${ }^{2}$ Nephrology, University Hospital, Leiden, The Netherlands
}

SUMMARY Ankylosing spondylitis (AS) is associated with $\operatorname{IgA}$ nephropathy. To study the pathogenetic mechanism of this association the presence of haematuria and circulating IgA containing immune complexes (IgA ICs) in 70 patients with AS was determined. In this retrospective study haematuria was present in 15 patients and 25 patients had $\operatorname{IgA}$ ICs. Circulating IgA ICs were shown in $9 / 15(60 \%)$ of the patients with haematuria and in $16 / 55(29 \%)$ of those without haematuria. These results suggest that IgA ICs in patients with ankylosing spondylitis have a pathogenetic role in causing IgA nephropathy.

Key words: nephropathy, pathogenic role.

Haematuria has been observed in patients with ankylosing spondylitis (AS). ${ }^{12}$ Recently several authors reported that IgA nephropathy may be part of the disease spectrum of AS. ${ }^{1-8}$ Primary IgA nephropathy is strongly associated with the presence of circulating $\operatorname{IgA}$ containing immune complexes (IgA ICs). ${ }^{9}$ This raises the question of whether nephropathy in AS is also related to the presence of IgA ICs. Conflicting data have been reported on the occurrence of circulating immune complexes in the sera of patients with AS. These differences may be explained by the use of different techniques for the detection of ICs and by differences in disease severity of the patients studied. ${ }^{10-17}$ In this study the presence of circulating ICs was studied with the indirect polymorphonuclear phagocytosis test (IPPT) and the C1q binding assay (C1qBA). The IPPT test allows the detection of different types of IC with one procedure. Previous studies showed a good correlation between the results of the IPPT for IgG and $\mathrm{IgA}$ and those of the $\mathrm{Clq}$ binding assay and IgA inhibition assay. ${ }^{18-20}$

We report on the associated presence of haematuria and circulating IgA ICs in a relatively large group of patients with AS.

Accepted for publication 10 February 1988.

Correspondence to Dr André J Pecters. Department of Rheumatology, Building 1, C2-Q, University Hospital, PO Box 9600, 2300 RC Leiden, The Netherlands.

\section{Patients and methods}

Seventy patients satisfying the modified New York criteria for $\mathrm{AS}^{21}$ were included in the study. All were patients attending our outpatient clinic over a period of four months, 11 were female. The mean age of the patients was 32 years (range 23-60) and the mean duration of disease after diagnosis was 13 years (range 1-40). The HLA-B27 antigen was present in $65 / 70(93 \%)$ patients, 54 patients were treated with non-steroidal anti-inflammatory drugs (phenylbutazone in 29 cases, indomethacin in 14, propionic acid derivatives in nine, and tolmetin in two patients). Serum and urine samples were obtained simultaneously. The serum samples used were stored for less than three months and frozen and thawed only once.

Class specific ICs (IgG, IgA, and IgM) were measured by the IPPT ${ }^{18-20}$ and by a modified C1qBA. ${ }^{22}$ In the IPPT $350 \mu \mathrm{l}$ of test serum was diluted with $400 \mu \mathrm{l} 0 \cdot 1 \mathrm{M}$ borate buffered saline, and $6 \times 10^{6}$ polymorphonuclear cells from a single healthy donor were added. The mixture was incubated at $37^{\circ} \mathrm{C}$ for 90 minutes. The cells were then washed three times and smeared on glass microscope slides, fixed $(95 \%$ ethanol $/ 5 \%$ acetic acid for 15 minutes at $-20^{\circ} \mathrm{C}$ ), washed, and stained with fluorescein isothiocyanate (FITC) conjugated goat antihuman IgG $(\mathrm{Fc})$, or FITC conjugated heavy 
chain specific rabbit antibodies against human IgM or human $\operatorname{IgA}$. Slides were then examined by fluorescence microscopy, and the number of cells showing granular fluorescent inclusions was expressed as a percentage after counting 100 cells. The IPPT was defined as abnormal for samples exceeding the mean $+2 \mathrm{SD}$ of 20 healthy donors. Association between haematuria and circulating IgA ICs was tested by $\chi^{2}$ test with Yates's correction. Statistical significance regarding erythrocyte sedimentation rate (ESR) was calculated with the Mann-Whitney U test.

\section{Results}

Microscopic haematuria (more than five red blood cells per high power field) was found in $15(21 \%)$ of the 70 patients with AS studied. One patient had 2+ proteinuria as measured by stick testing. No other patient had proteinuria, a history of renal disease, or a serum creatinine concentration in excess of 120 $\mu \mathrm{mol} / \mathrm{l}$. Two $(13 \%)$ of these patients were female; all except one male patient were positive for HLA-B27.

The 55 patients without haematuria did not differ from the group with haematuria in age, duration of symptoms, and sex distribution. All had a serum creatinine concentration below $120 \mu \mathrm{mol} / \mathrm{l}$ and none had a significant proteinuria.

The mean ESR in the patient group with haematuria was $25 \cdot 1 \mathrm{~mm} / \mathrm{h}$ (range $6-54)$. This was significantly higher than the $15.3 \mathrm{~mm} / \mathrm{h}$ (range $1-44)$ in patients without haematuria $(p=0 \cdot(2)$.

$\operatorname{Ig}$ A ICs were detected in $25(36 \%)$ of patients with AS, IgG containing ICs in six $(9 \%)$, and one patient had IgM ICs as measured with the IPPT. The results of the ClqBA were available from 40 patients. The serum of one patient contained ICs as measured by the ClqBA. Circulating IgA ICs were detected in $9 / 15(60 \%)$ of the patients with haematuria and in only $16 / 55(29 \%)$ of the patien s without haematuria. This difference was statistically significant $(p=0 \cdot(03)$. None of the six patients with circulating IgG ICs as measured by IPPT had IgA ICs and only one of them had haematuria.

Haematuria in the patients with AS studied was not related to current treatment with non-steroidal anti-inflammatory drugs (NSAIDs). The presence of haematuria in patients with AS treated with NSAIDs was also unrelated to any particular kind of drug or the duration of this treatment.

\section{Discussion}

These results show that there is an association between microscopic haematuria and circulating IgA ICs in patients with AS. Renal involvement in patients with AS includes amyloidosis ${ }^{23}$ and NSAID related nephropathies such as papillary necrosis and tubulointerstitial nephritis. ${ }^{24} 25$ Older histological studies found glomerulonephritis with renal vasculopathy in AS, and more recent studies report the presence of $\operatorname{IgA}$ nephropathy. ${ }^{1-826}$

We were not able to provide histological con- $\frac{\mathscr{\rho}}{\mathscr{D}}$ firmation of the renal disease in the patients with AS尺 studied. All had normal renal function and kidney® biopsies were not performed. These patients, $\overrightarrow{0}$ however, had no other diseases known to affect the? kidney or evidence of urinary tract disease. The $\vec{\omega}$ absence of marked proteinuria does not favour the presence of amyloidosis. The absence of a relation between haematuria and NSAID treatment, alsos found in an earlier study on patients with rheuma-io toid arthritis, ' makes NSAID related nephropathieso less likely. The high ESR in the patients with AScr with haematuria suggests a more active disease than in those without haematuria. More clinical informa tion on disease activity was not available in this retrospective study.

We found haematuria in $15 / 70(21 \%)$ of patient $\stackrel{\text { क }}{=}$ with AS studied, which agrees with some reports ${ }^{1}{ }^{2} \overrightarrow{0}$ but contrasts with others. ${ }^{27} 28$ The presence of $\operatorname{IgA}{ }_{\infty}^{\infty}$ ICs in AS has been reported previously, ${ }^{29}$ but the relation between haematuria and circulating $\operatorname{IgAO}$ ICs in AS has not been studied before.

IgA nephropathy seems to be part of the diseasea spectrum of ankylosing spondylitis. In IgA nephro유 pathy clinical and experimental data suggest tha circulating IgA ICs lead to mesangial IgA depositso and tissue injury. ${ }^{31}$ The fact that not all patients with? haematuria had IgA ICs may be explained by findings in studies on patients with IgA nephro pathy, which showed that these immune complexe can be present intermittently." Alternatively, the use of more assays available for the detection of $\operatorname{Ig} \mathrm{A}$. ICs may yield a higher percentage of patients with AS and circulating IgA ICs.

The association of IgA ICs and AS, and especiallyo of IgA ICs and AS with haematuria, favours as similar pathogenetic process for the development of IgA nephropathy in a part of the AS population

Further evidence for this hypothesis could bळ obtained from a prospective study on haematurian and circulating ICs in patients with AS whichN should include a full urological investigation, de tailed analysis of the IgA containing ICs, and possible renal biopsies.

We are greatly indebted to Mrs $\mathrm{H} H$ de Rooy-Dijk for her technical assistance, Ms J Ravensbergen and Ms A A J P Postma for theis secretarial assistance, and Dr F C Breedveld for his discussion an advice.

\section{References}

1 Wall B A. Agudelo C A. Pisko E J. Increased incidence 
of recurrent hematuria in ankylosing spondylitis: a possible association with IgA nephropathy. Rheumatol Int 1984; 4: 27-9.

2 Chou C T, Lee C F, Shieh S D, Huang H W, Ho Y S. The significance of raised serum $\operatorname{IgA}$ in ankylosing spondylitis with IgA nephropathy. Journal of the Formosan Medical Association 1984; 83: 1232-7.

3 Jennette J C, Ferguson A L, Moote M A, Freeman D G. IgA nephropathy associated with seronegative spondylarthropathies. Arthritis Rheum 1982; 25: 144-9.

4 Van Liebergen F J H M, Assman K J M, Koene R A P, van de Putte L B A. IgA nephropathy and ankylosing spondylitis [Abstract]. Kidney Int 1983; 24: 408.

5 Bailey R R, Burry A F, McGiven A R, Kirk J A, Laing J K, Moller P. A renal lesion in ankylosing spondylitis. Nephron 1980; 26: 171-3.

6 Shu K H, Lian J D, Yang Y F, et al. Glomerulonephritis in ankylosing spondylitis. Clin Nephrol 1986; 25: 169-74.

7 Bruneau C, Villiaumey J, Avouac B, et al. Seronegative spondylarthropathies and IgA glomerulonephritis: a report of four cases and a review of the literature. Semin Arthritis Rheum 1986; 15: 179-84.

8 Sissons J G P, Woodrow D F, Curtis J R, Evans D J, Gower P E, Sloper J C. Isolated glomerulonephritis with mesangial IgA deposits. Br Med J 1975; iii: 611-4.

9 Valentijn R M, Kauffmann R H, Brutel de la Rivière G, Daha $M R$, van Es L A. Presence of circulating macromolecular IgA in patients with hematuria due to primary $\operatorname{IgA}$ nephropathy. Am J Med 1983; 74: 375-81.

10 Duquesnoy B, Santoro F, Wattre P, Delcambre B. Failure to find C1q-binding material and anti-IgG antibodies in ankylosing spondylitis. Ann Rheum Dis 1980; 39: 449-52.

11 Maksymowych W, Dasgupta M K, Rothwell R S, Dossetor J B, Russell A S. The absence of circulating immune complexes in patients with ankylosing spondylitis. Rheumatol Int 1981; 1: 107-9.

12 Panayi G S, Slaney J, Williams B D. Circulating immune complexes in patients with ankylosing spondylitis. Ann Rheum Dis 1980; 39: 445-8.

13 Rosenbaum J T, Theofilopoulos A N, McDevitt H O, Pereira A B, Carson D, Calin A. Presence of circulating immune complexes in Reiter's syndrome and ankylosing spondylitis. Clin Immunol Immunopathol 1981; 18: 291-7.

14 Gabay R, Zubler R H, Nydegger U E, Lambert P H. Immune complexes and complement catabolism in ankylosing spondylitis. Arthritis Rheum 1977; 20: 913-6.

15 Espinoza L R, Gaylord S W, Bocanegra T S, Vasey F B, Germain B F. Circulating immune complexes in the seronegative spondyloarthropathies. Clin Immunol Immunopathol 1982; 22: 384-93.
16 Prakash S, Bansal R, Rajagopalan P, Malaviya A N. Immunological studies in seronegative spondyloarthropathies. $\mathrm{Br} J$ Rheumatol 1983; 22: 146-50.

17 Bruneau C, Bonin H. Evidence for a disease specific antigen in circulating immune complexes in ankylosing spondylitis. Clin Exp Immunol 1983; 53: 529-35.

18 Kauffmann R H, de Rooy-Dijk H H, Klein F, Lafeber G J M, Cats $A$, van Es $L A$. The significance of immunofluorescent immunoglobulin inclusions in polymorphonuclear leucocytes for the detection of circulating immune complexes. Clin Exp Immunol 1983; 54: 203-12.

19 Steven M M, Westedt M L, Daha M R, de Vries E, Cats A. Comparison of immune complexes and complement components in arterial and venous blood of patients with rheumatoid arthritis. J Rheumatol 1986; 13: 74-8.

20 Breedveld F C, Lafeber G J M, de Vries E, Leijh P C J, Daha M R, Cats A. Fc receptors on granulocytes from patients with rheumatoid arthritis and Felty's syndrome. Clin Exp Immunol 1984; 55: 677-83.

21 Van der Linden S, Valkenburg H A, Cats A. Evaluation of diagnostic criteria for ankylosing spondylitis. Arthritis Rheum 1984; 27: 361-8.

22 Zubler R H, Lange G, Lambert P H, Miescher P A. Detection of immune complexes in unheated sera by modified ${ }^{125} \mathrm{I}-\mathrm{C} 1 \mathrm{q}$ binding test. J Immunol 1976; 116: 232-5.

23 Hajjaj-Hassouni N, Laghrissi S, Khalil A, et al. Spondylarthrite ankylosante et amylose. Rev Rhum Mal Osteoartic 1982; 49: 687-91.

24 Lourie S H, Denman S J, Schroeder E T. Association of renal papillary necrosis and ankylosing spondylitis. Arthritis Rheum 1977; 20: 917-21.

25 Clive D M, Stoff J S. Renal syndromes associated with nonsteroidal antiinflammatory drugs. New Engl J Med 1984; 310: 563-72.

26 Pasternack A, Törnroth T, Martio J. Ultrastructural studies of renal arteriolar changes in ankylosing spondylitis. Acta Pathologica et Microbiologica Scandinavica; Section A: Pathology 1971; 79: 591-603.

27 Swaak A J G, Frankfort I, Menon R S, Pekelharing J M Planten $\mathrm{O}$. Absence of $\operatorname{IgA}$ nephropathy in patients with ankylosing spondylitis. Rheumatol Int 1986; 6: 145-9.

28 Calin A. Rarity of nerhropathy in ankylosing spondylitis Arthritis Rheum 1982; 25: 1510-1.

29 Deicher H, Ebringer A, Hildebrand S, Kemper A, Zeidler H. Circulating immune complexes in ankylosing spondylitis. $\mathrm{Br} \mathrm{J}$ Rheumatol 1983; 22 (suppl 2): 122-7.

30 Rifai A, Millard K. Glomerular deposition of immune complexes prepared with monomeric or polymeric IgA. Clin Exp Immunol 1985; 60: 363-8. 